Article

\title{
Patterns of Effective Pollen Dispersal in Larch: Linking Levels of Background Pollination with Pollen Dispersal Kernels
}

\author{
Jarosław Burczyk ${ }^{1, *(1)}$, Elżbieta Sandurska ${ }^{1}$ and Andrzej Lewandowski ${ }^{2}$ (D) \\ 1 Kazimierz Wielki University, Department of Genetics, Chodkiewicza 30, 85-064 Bydgoszcz, Poland; \\ ekoral@ukw.edu.pl \\ 2 Institute of Dendrology, Polish Academy of Sciences, Parkowa 5, 62-035 Kórnik, Poland; \\ alew@man.poznan.pl \\ * Correspondence: burczyk@ukw.edu.pl
}

Received: 12 November 2019; Accepted: 10 December 2019; Published: 12 December 2019

\begin{abstract}
Monitoring patterns of mating and pollen dispersal in forest tree populations subjected to nature conservation is essential to understanding the dynamics of their reproductive processes and might be helpful in making management decisions aimed at conserving genetic diversity and integrity over the long term. However, little is known about effective pollen dispersal in natural populations of conifers, particularly in subdominant species such as larch. We investigated patterns of pollen dispersal in the Polish larch population of Świętokrzyski National Park. The studied population was located on Chełmowa Mountain in a forest complex 160 ha in size, which is relatively isolated from other forest stands. We assessed if local pollen dispersal inferred from pollen dispersal kernels could provide indications of the level of background pollination from sources located outside of the forest complex. The analysis focused on two plots, each encompassing 126 adult trees, and seed samples $(n=600)$ collected from 20 trees. Using 11 nuclear microsatellites and spatially explicit mating models, we identified details of mating patterns. The rate of self-fertilization was low (0.0268). Background pollination was moderate (0.4058), and the mean pollen dispersal was found to be $167 \mathrm{~m}$ and $111 \mathrm{~m}$, based on exponential-power and Weibull dispersal kernels, respectively. Specific simulations performed based on the estimated pollen dispersal kernels provided background pollination levels comparable to those observed for real data, suggesting that the pollen contributing to background pollination likely originated from the studied forest complex and not from other surrounding populations. These results confirm the high potential for maintaining the genetic integrity of the larch population and support efforts aimed at promoting regeneration of the stands, either natural or through the artificial planting of seedlings derived from trees growing in the core larch population of the protected area.
\end{abstract}

Keywords: Larix decidua; mating system; pollen dispersal; paternity analysis; gene flow; dispersal kernel; selection gradient; microsatellite markers

\section{Introduction}

Genetic diversity is one of the main assets of natural populations. In forest trees, genetic diversity is considered the primary determinant of ecosystem sustainability and resilience of populations to environmental change, including climate change and the excessive exploitation of populations due to human activities [1]. The genetic diversity of natural populations is explored and utilized in tree improvement programs, for example, those aimed at increasing timber production in plantation forestry, which is important to the economies of many countries. However, managing the genetic 
resources of forest trees is challenging [2,3]. In temperate zones, different tree species present a large variety of population types: from species with scattered and isolated groups of trees to stand-forming tree species growing in large continuous populations, often spanning several countries. Therefore, the matter of how to approach conservation genetics in forest trees has been the subject of intense debate over recent decades [1,3].

Genetic diversity is a major concern in relation to populations of forest trees growing in conservation areas such as nature reserves or national parks [1]. Such populations usually have multiple features justifying their conservation (e.g., native origin, longevity, diversity of conspecific species), and the goal of conservation is to promote their long-term sustainability [4,5]. However, the ability of populations to maintain their genetic diversity across generations depends not only on the effective size of a population [6] but also on the mode of reproductive processes [7].

In our earlier study [8], we investigated the genetic diversity of the population of Polish larch (Larix decidua subsp. polonica (Racib. Domin)) growing on Chełmowa Mountain in Świętokrzyski National Park, Poland, which has been subject to conservation efforts since 1920. Chełmowa Mountain is a unique site, from which this form of larch was described for the first time as a separate species (Larix polonica) by Raciborski [9]. Now, Polish larch is considered a subspecies of European larch (Larix decidua Mill.) [10]. It has been found to be relatively resistant to drought [11] and larch canker [12,13], the primary threats potentially related to climate change. In our study, we found that the population was characterized by a relatively high level of genetic diversity, large effective population size, significant fine-scale spatial genetic structure highlighting its natural establishment, as well as relative homogeneity and a close genetic relationship with other Polish lowland larch populations. These results firmly justified the need to protect this population.

This protected population is relatively old, and the oldest trees are gradually thinning out. One option of the management plan is to stimulate natural regeneration or even use seedlings derived from seeds harvested from local larch trees. It is believed that despite an extensive artificial seed transfer across Europe, the larch populations of lowland Poland, including those of the Świętokrzyskie Mountains, have only been minimally affected by allochthonous plant material in comparison with other areas in Europe [14]. However, since the beginning of the 19th century, local foresters have introduced European larch to the forests in the Świętokrzyskie Mountains area [15,16], and these populations, mostly with unknown origin, might be a current source of pollen fertilizing local Polish larch trees. Therefore, the main gene conservation concern is to what extent the population of Polish larch protected on Chełmowa Mountain is capable of maintaining its integrity in the face of potential gene flow from surrounding larch populations.

Pollen mediated gene flow in forest trees might be extensive [17,18]; however, studies of patterns of pollen dispersal in natural populations of larch are lacking. In the context of conservation genetics, the possibility of gene immigration has two main implications. On one hand, it could be the source of new allelic variation, potentially increasing the genetic diversity of local populations, thus counteracting the adverse effects of inbreeding or genetic drift. On the other hand, if populations subjected to conservation are exposed to gene flow from non-native populations, gene immigration may eventually erode genetic diversity and disrupt the integrity of conserved populations [19-21]. Therefore, monitoring the conservation status of populations should include not only the assessment of demography or genetic diversity but also monitoring mating patterns, including gene flow. This could be helpful in making management decisions aimed at preserving the genetic diversity of conserved populations in the long term $[1,6,19,21]$.

One way to investigate patterns of effective pollen dispersal in trees is to apply parentage analysis based on genetic markers, with the aid of specially designed statistical methods [22,23]. Several recent studies, in both conifers and angiosperms, demonstrated that the probability of pollen dispersal decreases with distance [24-26]. However, at the same time, considerable proportions of offspring result from mating with pollen donors located outside of local populations (considered often as background pollination or pollen immigration) $[17,27,28]$. This is because local pollen dispersal (at the scale of 
tens to hundreds of meters) is governed by gradient processes, but long-distance pollen dispersal at the mesoscale is a more complex and highly unpredictable event due to specific multidimensional atmospheric processes affecting air movements [29,30]. Currently available methods for studying pollen dispersal generally fail to connect background pollination levels to patterns of local pollen dispersal as described by dispersal kernels, with some exceptions [31,32].

In this study, we investigated patterns of effective pollen dispersal in the conserved Polish larch population growing in a relatively isolated forest complex of Chełmowa Mountain. We used nuclear microsatellites and spatially explicit mating models to assess pollen dispersal kernels and to identify possible determinants of male mating success. We were particularly interested to see if patterns of local pollen dispersal could be helpful in explaining the observed background pollination levels and how this information could affect management decisions aimed at efficient conservation of the studied population. We believe that this case study will broaden our understanding of the reproductive biology of larch species, but also conifers in general, and will facilitate further research on pollen-mediated gene flow occurring at the mesoscale, which is essential for conservation genetics and adaptive processes of populations in the context of climate change [1,6].

\section{Materials and Methods}

We investigated mating patterns in Polish larch (Larix decidua subsp. polonica (Racib. Domin) growing on two plots in the Chełmowa Mountain Nature Reserve, in the forest district of Łagów, Poland. Plot A was located in sectors A-1h and A-1i, and consisted of larch trees over 190 years old, which shared 30\%-40\% of the stand, coexisting with oak (Quercus robur L.) and beech (Fagus sylvatica L). Plot B was located in sectors A-3c, in which the larch trees were slightly younger (about 170 years old). These trees also shared about $40 \%$ of the stand but coexisted with beech trees only. Each plot was represented by 126 adult trees, which were measured for $\mathrm{DBH}$ (diameter at breast height) and height and were georeferenced. The plots were roughly oval shaped with diameters of around $250 \mathrm{~m}$ for plot A and $220 \mathrm{~m}$ for plot B. The distance between the plots was ca. $600 \mathrm{~m}$. The entire forest complex was about 160 ha in size, and it was relatively isolated from other nearby forests (Figure 1). The nearest stands with larch are located $2.2 \mathrm{~km}$ due southwest and $5 \mathrm{~km}$ south. Details of the sampled subpopulations (locations, areas, etc.) are presented in Table S1. In each plot, ten trees were selected as mother trees and sampled for cones by shooting branches in February and March 2018. From each mother tree, 30 seeds were germinated, and the emerged seedlings were genotyped.

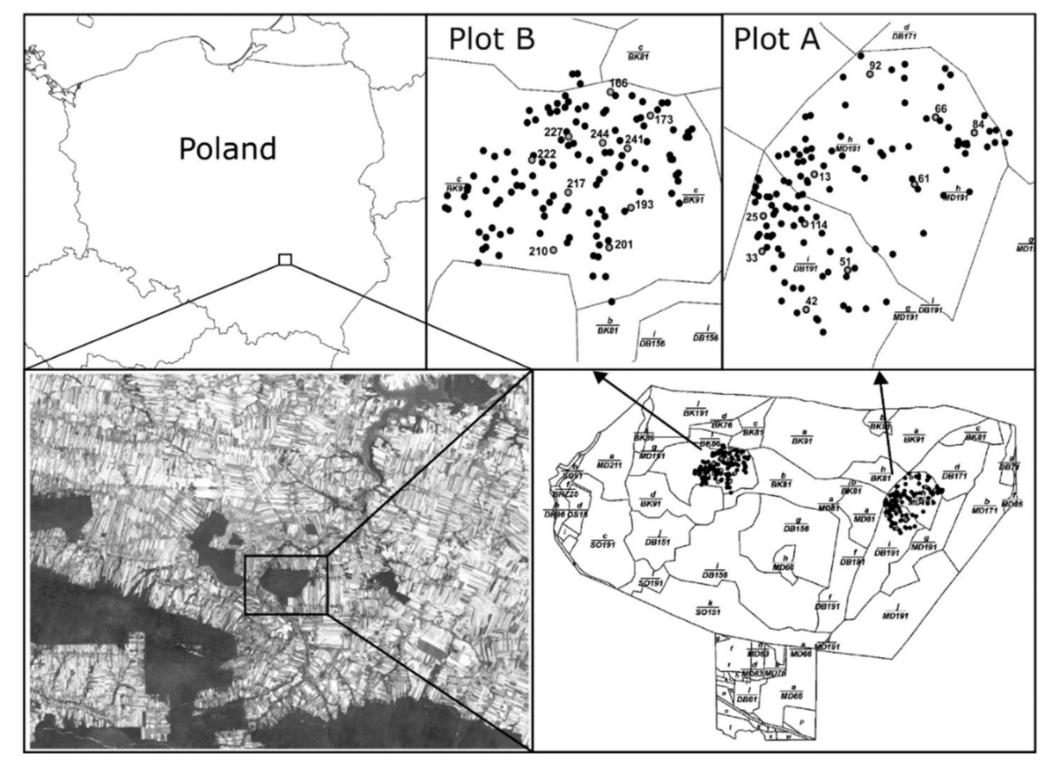

Figure 1. Location of the studied forest complex, including the two sample plots (plot A and plot B) and the distribution of sampled adult individuals. 
Total genomic DNA was extracted from fresh tissue of germinated embryos or small seedlings using the GeneMATRIX Plant \& Fungi DNA Purification kit (EURx Ltd., Gdansk, Poland) following the manufacturer's protocol. All adult individuals and seedlings were genotyped at eleven nuclear microsatellite markers (SSRs): bcLK189, bcLK211, bcLK229, bcLK228, bcLK263, LD31, LD42, LD45, LD50, LD56, LD101. Details of the genotyping procedures are presented in [8]. Adult genotypes used for parentage analyses, assessed with the same set of microsatellite loci, originated from our previous study [8].

Basic genetic diversity parameters and inbreeding coefficients, accounting for the presence of null alleles, were estimated using INEst v. 2.0 software [33]. The effective population size $\left(N_{\mathrm{e}}\right)$ of offspring cohorts was calculated based on the linkage disequilibrium (LD) method implemented in NeEstimator 2.01 software [34], assuming a random mating model and a threshold of excluding rare alleles at $\mathrm{P}_{\text {crit }}=0.02$. Parameters of the mating system were obtained based on a spatially explicit mating model (neighborhood model $[35,36]$ ) using the NM $\pi$ computer program [37]. The effects of tree height and DBH on male mating success were estimated based on standardized measures. The analyses were conducted separately for each plot and jointly for the entire dataset. Mating system parameters for individual mother trees were estimated using NM2F software [38]. Estimates were derived with 10,000 MCMC samples, saving every 10th update. Probabilities of paternal identities (PPIs) were used to infer effective numbers of background pollen parents $\left(N_{e p \text { BAC }}\right)$, according to [39]. Effective numbers of local pollen parents were calculated based on inferred genealogies following the results of $\mathrm{NM} \pi$ based on the full model $N_{e p \mathrm{LOC}}=1 / \Sigma \phi_{j}{ }^{2}$, in which $\phi_{j}$ is the proportion of offspring of a given mother tree sired by $j$-th male within the sample plot. The total effective number of pollen parents $\left(N_{e p}\right)$ for each mother tree was calculated as the harmonic mean of $N_{e p \text { BAC }}$ and $N_{e p \text { LOC }}$.

Given the estimates of parameters of pollen dispersal kernels, we performed simple simulations aimed at investigating patterns of pollen dispersal outside of the sampled plots but still within the studied forest complex. We generated the population of adults distributed on a circular grid of $10 \times 10 \mathrm{~m}$ (density 100 trees/ha), with a radius of $715 \mathrm{~m}$, totaling an area of $160.5 \mathrm{ha}$, similar to the area of the studied forest complex. The focal female was placed in the center of the simulated population. For each adult in the simulated population, the probability of mating with the focal female was calculated based on the equation (3) presented in [37]. We calculated the proportion of summed probabilities of males located within the arbitrarily defined neighborhood area (radius $r$ ) relative to the summed probabilities of all males located in the entire simulated population (radius $715 \mathrm{~m}$ ). In these simulations, we assumed a uniform spatial distribution of all males within the population, and that male mating success of individuals depended only on the distance and direction of a male relative to the focal female, and that all mating events occurred only within the simulated population (with no immigration from outside of the circle). However, because the dispersal kernel is estimated solely based on local outcross mating events, for simplicity we also assumed no selfing.

\section{Results}

\subsection{Genetic Diversity of the Offspring Generation}

Six hundred seedlings were successfully genotyped at 11 microsatellite loci. Only 22 diploid genotypes of 6600 (11 loci $\times 600$ seedlings), were missing. Seedling genotypes were compared to respective mother genotypes to ensure appropriate allele calling. The seedlings demonstrated high levels of genetic diversity, similar to those of adult populations; however, the offspring cohorts exhibited a slightly larger mean number of alleles per locus than the adults (Table 1). A significant level of inbreeding was noticed among offspring originating from Plot A. The effective population size of offspring samples was estimated to be 40.8 (95\% C. I.: 36.3-45.8) for Plot A and 55.0 (95\% C.I.: 48.4-62.5) for plot B. Given that the offspring were sampled equally from 10 mother trees, these effective numbers are relatively high. 
Table 1. Parameters of genetic diversity of adults and offspring at two sample plots ( $N$-number of individuals; $A$-mean number of alleles per locus; $H_{\mathrm{o}}$-observed heterozygosity; $H_{\mathrm{e}}$-expected heterozygosity; $F_{\text {is }}$ null—fixation index estimated accounting for null alleles; Freq.Null—mean frequency of null alleles. Results for adults originate from [8].

\begin{tabular}{ccccccc}
\hline Population & $\boldsymbol{N}$ & $\boldsymbol{A}$ & $\boldsymbol{H}_{\mathbf{o}}$ & $\boldsymbol{H}_{\mathbf{e}}$ & $\boldsymbol{F}_{\text {is }}$ null & Freq. $\boldsymbol{N u l l}$ \\
\hline Plot A-adults & 126 & 9.5 & 0.672 & 0.691 & 0.005 & 0.030 \\
Plot B-adults & 126 & 9.6 & 0.709 & 0.722 & 0.005 & 0.030 \\
Plot A-offspring & 300 & 10.82 & 0.663 & 0.703 & $0.023^{\mathrm{a}}$ & 0.028 \\
Plot B-offspring & 300 & 11.73 & 0.676 & 0.713 & 0.008 & 0.030 \\
\hline
\end{tabular}

a significant at 0.05 .

\subsection{Neighborhood Model Selection and Genotyping Errors}

Initially, NM $\pi$ was run for the entire data set (600 seedlings, 252 adults from both plots) with different combinations of parameters included in subsequent models. We started the estimation process with a model that included selfing $(s)$ and background pollination $\left(m_{\mathrm{p}}\right)$, along with a vector of genotyping error rates $(\varepsilon)$. Other parameters were consecutively added to the model, including dispersal kernel parameters, anisotropy parameters, and selection gradients. Parameters were retained in the model if they significantly improved the model in terms of the log-likelihood ratio. Although tree height, when considered separately, was found to be a significant covariate of mating success, it was found to be insignificant when included in the model jointly with tree DBH. Therefore, only selection gradients related to DBH were retained in the final model. There was no interaction between tree height and DBH.

Our final model, retaining only significant parameters, included: selfing $(s)$, background pollination $\left(m_{\mathrm{p}}\right)$, two dispersal kernel parameters (inverse of mean pollen dispersal distance- $-d_{\mathrm{p}}$ and shape parameter- $-b_{\mathrm{p}}$ ), two dispersal anisotropy parameters (intensity of anisotropy $-k_{\mathrm{p}}$ and prevailing direction of dispersal $-a_{\mathrm{p}}$ ), linear and quadratic selection gradients relating male mating success to $\mathrm{DBH}\left(\beta_{\mathrm{DBH}}\right.$ and $\left.\beta_{\mathrm{DBH}}{ }^{2}\right)$ and the vector of genotyping error rates $(\varepsilon)$. This model was applied to the data originating from each plot separately (300 seedlings and 126 adults in each case). Patterns of pollen dispersal were assessed based on exponential-power and Weibull dispersal kernels; however, in all cases, the exponential-power kernel provided a slightly (although not significantly) better model fit than the Weibull kernel. Therefore, our primary results are presented based on the exponential-power dispersal kernel only.

When applying the final model to the entire dataset, all 11 loci exhibited significant levels of genotyping error (Table S2), with a mean error level equal to 0.042. Error rate estimates were correlated between the two sample plots $(r=0.8949 ; p=0.0002)$. However, given that the NM $\pi$ software efficiently handles a wide range of genotyping errors [37], we decided to use all loci in the parentage analyses. Genealogies of offspring established based on the full mating model, using NM $\pi$, indicated that $448(75 \%)$ seedlings had their paternity defined at probability $>0.95$, and $535(89.2 \%)$ seedlings at probability $>0.80$.

\subsection{Mating System, Pollen Dispersal, and Selection Gradients}

Self-fertilization was found to be significant at plot A, but not at plot B (Table 2), with a significant estimate obtained for the entire dataset $(s=0.0268)$. The level of background pollination was also variable among the plots, with a lower estimate at plot $\mathrm{A}\left(m_{\mathrm{p}}=0.3501\right)$ than at plot $\mathrm{B}\left(m_{\mathrm{p}}=0.4427\right)$ (Table 2). The background pollination level estimated based on the entire dataset was 0.4058 . All of these estimates were significant. 
Table 2. Parameters of the mating system, pollen dispersal, and selection gradients estimated by the neighborhood model (SD in parentheses; significant estimates $(p<0.05)$ are marked in bold).

\begin{tabular}{cccc}
\hline Mating Parameter & Plot A & Plot B & Both Plots Jointly \\
\hline Self-fertilization $(s)$ & $\mathbf{0 . 0 4 5 8 ( 0 . 0 1 2 6 )}$ & $0.0090(0.0060)$ & $\mathbf{0 . 0 2 6 8}(0.0068)$ \\
Background pollination $\left(m_{\mathrm{p}}\right)$ & $\mathbf{0 . 3 5 0 1}(0.0310)$ & $\mathbf{0 . 4 4 2 7}(0.0312)$ & $\mathbf{0 . 4 0 5 8}(0.0221)$ \\
Inverse of the pollen mean dispersal distance $\left(d_{\mathrm{p}}\right)$ & $0.0067(0.0037)$ & $0.0032(0.0046)$ & $\mathbf{0 . 0 0 6 0}(0.0030)$ \\
Shape parameter of exponential-power kernel $\left(b_{\mathrm{p}}\right)$ & $\mathbf{0 . 3 1 9 1 ( 0 . 1 0 0 3 )}$ & $0.2552(0.1501)$ & $\mathbf{0 . 3 1 7 6}(0.0861)$ \\
Pollen dispersal anisotropy $\left(k_{\mathrm{p}}\right)$ & $\mathbf{1 . 4 0 8 3 ( 0 . 1 6 0 1 )}$ & $\mathbf{1 . 5 3 6 0}(0.1717)$ & $\mathbf{1 . 4 5 3 9}(0.1162)$ \\
Prevailing direction of pollen dispersal $\left(a_{\mathrm{p}}\right)$ & $\mathbf{0 . 0 5 6 8}(0.0148)$ & $\mathbf{0 . 0 6 8 0}(0.0146)$ & $\mathbf{0 . 0 6 1 2}(0.0105)$ \\
Linear selection gradient $\left(\beta_{\mathrm{DBH}}\right)$ & $\mathbf{0 . 6 6 8 7}(0.1098)$ & $\mathbf{0 . 6 9 4 8}(0.1534)$ & $\mathbf{0 . 6 9 2 1}(0.0902)$ \\
Quadratic selection gradient $\left(\beta_{\mathrm{DBH}}{ }^{2}\right)$ & $\mathbf{- 0 . 2 2 9 8}(0.0598)$ & $-0.1125(0.1164)$ & $\mathbf{- 0 . 2 2 1 6}(0.0527)$ \\
\hline
\end{tabular}

The estimates for dispersal kernel parameters were relatively similar between the two plots (Table 2). Whilst SD estimates were high, retaining the kernel parameters (either exponential-power or Weibull) in the mating model had a highly significant effect on the model likelihood. The kernel parameters indicated that pollen dispersal was leptokurtic (fat-tailed), with a shape parameter of the exponential-power kernel of approximately 0.32 (Table 2). Dispersal kernel estimates indicated that the mean kernel dispersal distance ranged from approximately 110 to $>300 \mathrm{~m}$, depending on the dispersal kernel and the plot (Table 3). However, the exponential-power and Weibull kernels showed a generally similar shape in terms of kernel probability density distribution (Figure 2). The probability of dispersal drops off quickly up to a distance of about $20 \mathrm{~m}$, then decreases more slowly. This means that there is a high probability of mating between near neighbors, while more distant male trees have a distinctly lower probability of mating with a given female. Indeed, the detailed analysis of seedling paternities based on the full model indicated several examples where a mother tree was successfully pollinated by a nearby male (eg.: $52 \rightarrow 51,7,6 \mathrm{~m} ; 65 \rightarrow 66,9,8.85 \mathrm{~m} ; 113 \rightarrow 114,8,17 \mathrm{~m}$; male $\rightarrow$ female, number of seedlings, distance). Interestingly, the most productive full-sib mating (22 seedlings) was with mother tree 42 , which was pollinated by nearby tree 43 located only $12.7 \mathrm{~m}$ away.

Table 3. Mean dispersal distances (in meters) estimated based on exponential-power and Weibull dispersal kernels with 95\% C.I.

\begin{tabular}{cccc}
\hline Mating Parameter & Plot A & Plot B & Both Plots Jointly \\
\hline Exponential-power dispersal kernel & & & \\
Mean kernel dispersal distance & 150.189 & 315.662 & 166.752 \\
Q [2.5\%] & 66.539 & 70.310 & 77.372 \\
Q [97.5\%] & $\infty$ & $\infty$ & $\infty$ \\
\hline Weibull dispersal kernel & & & \\
Mean kernel dispersal distance & 109.948 & 178.006 & 110.706 \\
Q [2.5\%] & 64.619 & 46.653 & 67.965 \\
Q [97.5\%] & 368.302 & $\infty$ & 298.295 \\
\hline
\end{tabular}

In addition to the analysis of dispersal kernels, it is also possible to explore actual pollen dispersal within the neighborhoods based on the inferred genealogies. In the case of the full model with exponential-power kernel, the mean pollen dispersal distance between sampled mothers and assigned pollen parents within the neighborhoods was $43.77 \mathrm{~m}$ (Figure S1). However, 50\% of locally sired offspring resulted from pollination with males located closer than $33.3 \mathrm{~m}$ from mother trees (Figure S2).

We found that, within neighborhoods, pollen was dispersed mostly towards the northern direction $\left(a_{\mathrm{p}}=6.12\right.$ translates to the azimuth of $22^{\circ}$, i.e., N-NE), and this pattern was consistent among the two sample plots (Table 2). The directionality of pollen dispersal was confirmed by highly significant estimates of anisotropy parameters $\left(k_{\mathrm{p}}\right)$.

It appeared that the DBH of male trees had a significant effect on male mating success. The mean $\mathrm{DBH}$ among all adult trees was found to be $72.3 \mathrm{~cm}(\mathrm{SD} \pm 18.61)$. Linear selection gradients related to DBH were significant in all analyzed datasets (Table 2), however, the quadratic selection gradient was 
not significant in plot B. Mating success increased with tree size (DBH), and the most successful males with diameter of ca. $100 \mathrm{~cm}$ were almost two times more successful than males with an average DBH (Figure 3). However, the significant negative estimate of the quadratic selection gradient indicated that male mating success increased with tree DBH to about $100 \mathrm{~cm}$, then gradually decreased, suggesting that an optimum tree DBH of around $100 \mathrm{~cm}$ maximizes male mating success. Trees with a diameter above $100 \mathrm{~cm}$ were found to be less successful, which might be related to their senescence.

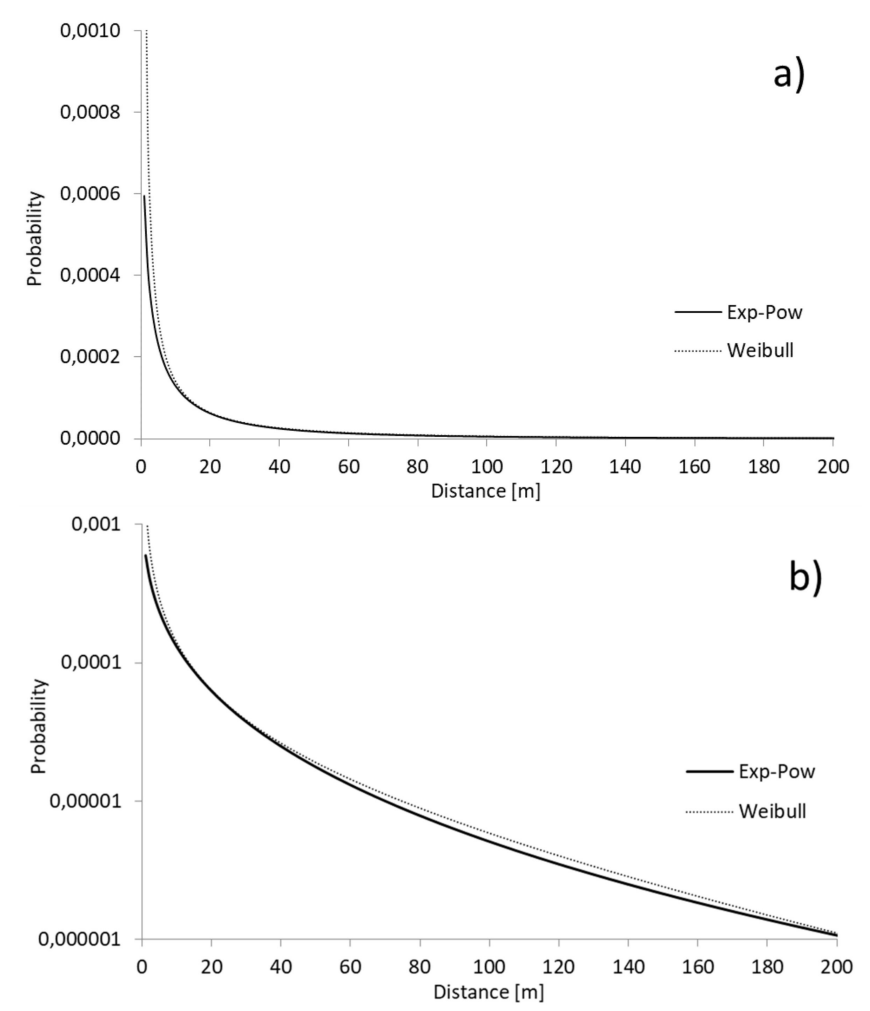

Figure 2. The probability density distribution of pollen dispersal estimated based on exponentialpower and Weibull kernels; (a) linear scale of probability, (b) logarithmic scale of probability.

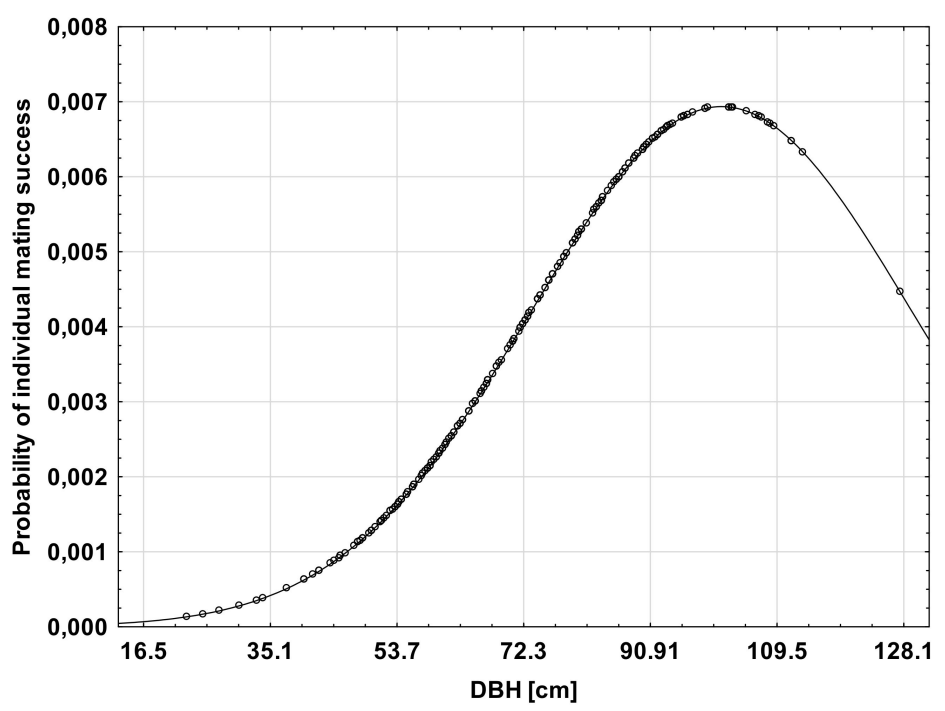

Figure 3. The relationship between individual male mating success and tree diameter at breast height (DBH). The DBH scale is adjusted to standardized $\mathrm{DBH}$ values with $\mathrm{DBH}=72.3$ (the sample mean) corresponding to $z=0, \mathrm{DBH}=16.5$ to $z=-3 S$, and $\mathrm{DBH}=128.1$ to $z=+3 S$, where $S$ is the standard deviation of the sample. 
Finally, more detailed analyses based on inferred genealogies revealed that the most successful $20 \%$ of males contributed to $67 \%$ of locally sired offspring, and 108 local males (42.5\%) did not father any of the sampled offspring. The remaining 144 males sired between 1 and 22 offspring (Figure S3). Using the inferred genealogies, we calculated the relative contributions $\left(\phi_{j}\right)$ of each male within the plot to the sample of investigated offspring and estimated the effective number of pollen parents based on the equation $N_{\mathrm{ep}}=1 / \Sigma \phi_{\mathrm{j}}{ }^{2}$. The effective number of local pollen parents was found to be 30.36 and 43.84 for plots $\mathrm{A}$ and $\mathrm{B}$, respectively. However, taking into account pollen immigration and assuming that the number of pollen donors in background populations is large [24], the total effective numbers of pollen parents were estimated as 81.60 and 144.93 for plots A and B, respectively. Finally, taking into account estimates of $N_{\mathrm{ep}}$ and the fact that the seeds were sampled from 10 mother trees, the overall effective numbers of offspring samples (including male and female components) could be estimated as $N_{\mathrm{e}}=\left(4 \times N_{\mathrm{ep}} \times 10\right) /\left(10+N_{\mathrm{ep}}\right)[40]$, with the resulting estimates equal to 35.63 and 37.42 for plots $\mathrm{A}$ and $\mathrm{B}$, respectively. These effective numbers were comparable to the effective numbers estimated based on the linkage disequilibrium method presented earlier. Finally, the locally sired offspring (348 seedlings) were the result of matings between 209 male $\rightarrow$ female pairs, with each pair being the parents of 1 to 22 offspring (Figure S4).

We also estimated mating system parameters for individual mother trees (Table S3). Individual selfing rates ranged from 0.008 to 0.099 . Selfing rates were significantly different from zero in six mothers in plot A and two mothers in plot B. The proportion of background pollination $(m)$ varied from 0.252 to 0.718 , and while mother trees located close to the edges of the plots generally had higher $m$ estimates (Figure S5), it was not the universal rule (e.g., tree 42, located at the southern edge of Plot A, had the lowest background pollination level, likely due to efficient pollination by tree 43 , see above). The plot means of individual estimates of $s$ and $m$ were in close agreement with the corresponding estimates obtained based on NM $\pi$ (Table 2). Effective numbers of background and local pollen parents were about 1.3 times larger for Plot B than for Plot A. The effective numbers were not correlated with the levels of selfing or background pollination.

\subsection{Background Pollination vs. Pollen Dispersal Kernel}

To study the relationship between the estimated pollen dispersal kernel and the background pollination level, we performed simple simulations. Using the parameters of the exponential-power kernel based on the full model and the entire dataset, assuming that all matings occur within the circular area of about 160 ha (the size of the forest complex), we found that the proportion of pollen immigration from outside of the neighborhood is approximately 0.4 (a value close to our estimate of $m=0.4058$, Table 2) when the neighborhood radius is roughly $115 \mathrm{~m}$ (Figure 4). Decreasing neighborhood size results in progressively increasing immigration levels. Analogously, for the Weibull kernel, the neighborhood size corresponding to an immigration level of 0.4 was found to be about $105 \mathrm{~m}$. It should be noted that, in this study, the designed sample plots had diameters of about 220-250 m; however, the mother trees were not strictly located in the center of the plots. Instead, they were situated in various parts of the plot with variable distances to the plot edge, which could have affected the observed background pollination levels. Therefore, it is reasonable to expect that some proportion of immigrant pollen could originate from males located just outside of the sample plots.

We reanalyzed our data set, adjusting the neighborhood size so that the level of background pollination was estimated at $m=0.5$, corresponding to the neighborhood size which is the median of the pollen dispersal distance. In the case of our study, the neighborhood size corresponding to $m \approx 0.5$ was equal to $84 \mathrm{~m}$ in both exponential-power and Weibull kernels. Note that the level of $m$ estimated in the NM $\pi$ is defined based on the paternity exclusion and not the shape of a dispersal kernel. In our simulations, the immigration level of $m=0.5$ corresponded to neighborhood sizes of approximately $85 \mathrm{~m}$ and $80 \mathrm{~m}$ for exponential-power and Weibull kernels, respectively.

In conclusion, comparing our results with simulations suggests that in the studied population, the majority of mating events likely occurred within the studied forest complex of 160 ha, assuming 
a similar density of larch trees within and outside of the neighborhoods (sampled plots). However, because the actual density of larch trees outside of the studied sample plots is not uniform, and is actually slightly lower than in the neighborhoods (based on forest inventory data; bdl.lasy.gov.pl), one might expect that a proportion of pollen (although small) could originate from outside of the forest complex.

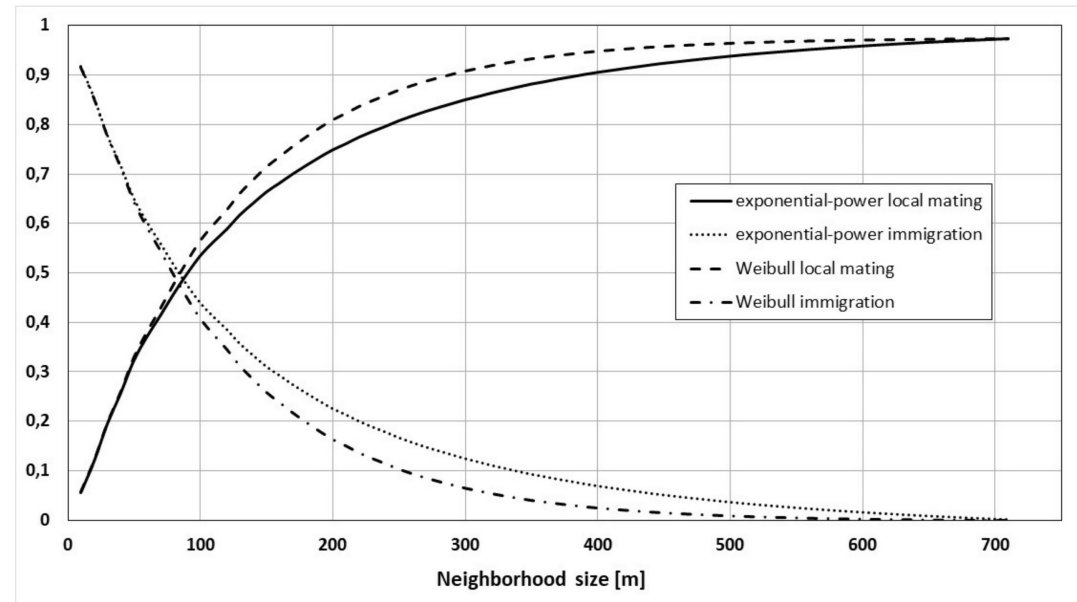

Figure 4. Relationships between the neighborhood size and the probability of local outcross mating $(1-s-m)$ within the neighborhood vs. pollen immigration $(m)$ from outside of the neighborhood, simulated based on the parameters of exponential-power and Weibull dispersal kernels estimated from real data. The simulations are made for the population distributed over the circular area with a radius of $715 \mathrm{~m}$, equivalent to the area of $160 \mathrm{ha}$, corresponding to the studied forest complex.

\section{Discussion}

Monitoring mating patterns and gene flow in natural forest tree populations is essential for managing their genetic resources [1,6]. Such monitoring is especially crucial in populations subjected to conservation in nature reserves and national parks [1], but also in other populations selected for gene conservation, such as GRMUs (gene resource management units, [41]) or GCUs (genetic conservation units, [3]). In this paper, we present the results of the analyses of the mating system and patterns of effective pollen-mediated gene flow in Polish larch located in the nature reserve of Chełmowa Mountain, Poland. Although, in general, our results conform with other similar studies of wind-pollinated forest trees, the conclusions resulting from this study should be considered with caution, as they are only based on a single seed crop. Specifically, patterns of pollen dispersal may vary year by year due to possible variations in meteorological variables and variation in masting affecting the potential for pollen dispersal [30].

The level of selfing found in this study translates to an outcrossing rate of $t=0.9732(t=1-s)$, which can be compared to earlier studies. In Larix species, the outcrossing rate has previously been found to be high, ranging from 0.85 to 0.97 [42-46], which is typical for other coniferous tree species [47], although occasionally, in case of pollen deficiency, the outcrossing rate can fall below 0.80 [48,49]. The level of selfing might be variable among sampled females [48]. In our case, small sampling sizes per mother (30 seeds) did not allow for a profound exploration of this variation, but we noticed few females with selfing rate close to $s=0.1$. Therefore, when seed harvesting is performed from a few individual mother trees, it is always advisable to monitor the level of selfing and effective numbers of pollen parents of individual half-sib families.

We found that around $40 \%$ of pollen resulted from mating with males located outside of the sampled plots. The two plots differed significantly in $m$ estimates (35\% vs. $44 \%$ ); however, the differences could be, to some degree, attributed to the sizes of the plots. The two plots were represented by 126 adult trees each, but due to some differences in tree density, the plots differed in area (Table S1), with Plot A 
being larger (4.40 ha) than Plot B ( 3.30 ha). Mother trees from which seeds were sampled were not located centrally but were distributed throughout the plot, and the differences in their location within the plots could also contribute to some differences in pollen dispersal parameters among the plots, especially in the background pollination levels. The parameters of dispersal kernels indicated that pollen dispersal is more extensive in plot $\mathrm{B}$ than in plot $\mathrm{A}$, which is in line with the higher proportion of $m$ observed in plot B. In conclusion, differences between the plots in $s$ and $m$ rates, and mean kernel pollen dispersal distances, suggest that, despite the differences in the plot sizes, pollen dispersal was more intensive in Plot B. The most likely reasons for these differences are differences in the coexisting tree species and site topography [30].

Most information about effective long-distance pollen dispersal in conifers comes from studies of pollen contamination in coniferous seed orchards $[17,19,50]$. Seed orchards are artificial populations established to promote mating among selected genotypes [51], and they are usually relatively isolated from conspecific stands to avoid background pollination. However, even then, the observed level of pollen immigration might be as high as 50\% [17,50]. Therefore, our estimates of background pollination obtained for sample plots being a part of a forest complex should be considered rather low.

Larix has relatively heavy pollen compared to other conifers and consequently has a lower capacity to disperse pollen over large distances [52]. The terminal velocity of larch pollen $\left(0.126 \mathrm{~ms}^{-1}\right)$ is 3-4 times higher than that of pines [52,53]. Larix is characterized by a relatively strong genetic structure among populations compared to other conifers [54], which might also be related to the limited ability of larch to disperse pollen over long distances. Some authors relate to lack of genetic differentiation among larch populations located at the northern limits of the species distribution to extensive gene flow [55]; however, mechanisms other than contemporary pollen mediated gene movement could also be responsible for the lack of population genetic structure.

Estimating pollen dispersal kernels based on genotypic data brings several challenges [23,26]. Direct genetic methods based on paternity analyses are particularly attractive tools for research, but they usually require exhaustive sampling of a potentially large number of paternal candidate individuals [22]. The sampling limitations of large continuous populations are problematic because the precision of parameters of fat-tailed dispersal kernels depend mainly on the number of distant dispersal events $[23,26,38,56]$, and limiting the area of sampling of potential paternal individuals (truncating the maximum dispersal distance within the plot) has negative impacts on the precision of kernel parameter estimates. Consequently, in many studies, the estimate of mean kernel dispersal distance is associated with wide confidence intervals, which is particularly evident for fat-tailed dispersal kernels $[23,32,38]$. The complexity of dispersal events (spatial or temporal variance) and the influence on probabilities of dispersal from other factors (tree density, topography, the variance of fecundities, etc.) contribute to imprecise definitions of dispersal kernels [23]. Because the probability of paternity is not exclusively related to the distance between mates, we extended our model, incorporating directionality parameters and selection gradients related to tree size, which significantly improved the likelihoods of the mating models applied.

The mean pollen dispersal distances presented in this study (111-167 m, depending on the kernel type) are comparable to or lower than those reported in previous studies in conifers $[31,57,58]$. The shape of the kernels indicated that mating is most likely among near neighbors; however, possible mating with distant males is also possible, resulting in fat-tailed (leptokurtic) dispersal kernels. Because of a limited range of actual local mating events within the plots, both tested kernels presented similar patterns of pollen dispersal (no significant difference between the exponential-power and Weibull kernels).

Linking pollen dispersal kernels with levels of observed background pollination seems to be one of the greatest challenges of the reproductive biology of forest trees [18], and of plants in general [23], because this problem involves the issue of long-distance pollen dispersal affecting adaptive processes which are critical in the context of climate change [18,59]. A substantial discrepancy between background pollination inferred from dispersal kernels and actual pollination estimates based on 
genetic exclusion could provide indirect evidence on the importance of mesoscale dispersal processes to effective pollen dispersal [29]. Several attempts have been made to link or explain background pollination based on dispersal kernels [31,32,56]. These methods usually assume that populations spanning outside of sampled plots have densities and fecundities similar to those observed within plots. Because, in this study, sample plots were located in a fairly isolated forest complex, surrounded largely by agricultural landscape, we performed simple simulations attempting to compare observed patterns of pollen dispersal (dispersal kernel) with expected (simulated) patterns, assuming that all mating events occurred within the simulated population comparable to our forest complex of about 160 ha in size. The similarity between the simulated and observed patterns of background pollination along various neighborhood sizes suggested that background pollination from outside of the forest complex is very unlikely. This is an important finding of the study in the context of conservation of genetic diversity of the population [1] indicating that the majority of seeds result from local pollination.

The importance of background pollen to the reproduction of a local population is likely governed by the abundance of pollen produced by local populations relative to the amounts of pollen released by background sources. In the case of stand-forming trees growing over large areas, such as some pine species, it is believed that large quantities of pollen can be effectively transported over considerable distances and still being capable of fertilization [29]. However, Larix covers only about $1.2 \%$ of the forested area of the Świętokrzyski National Park (ŚNP), and it is even less frequent in other forests surrounding the ŚNP. The larch population on Chełmowa Mountain is an unusual example of a forest stand dominated by large mature trees of this species. Therefore, our results reveal that it is reasonable to expect that the majority of female trees located on the reserve of the Chełmowa Mountain are pollinated within this somewhat isolated reserve. However, stands or forest compartments with larch trees of suspected non-local origin, such as those identified in our earlier study [8] should be gradually removed to assure the genetic integrity of the local core Polish larch population.

\section{Conclusions}

Monitoring mating patterns and gene flow is especially important in tree populations subjected to nature conservation efforts. Measures of pollen dispersal within stands, and pollen immigration into stands, may provide insights into dynamics of reproductive processes, and could be helpful in making management decisions aimed at conserving the genetic resources of local populations. The studied population of Polish larch, located in a relatively isolated forest complex (160 ha), exhibited acceptably low levels of selfing and moderate levels of background pollination. However, background pollination was measured as the proportion of offspring sired by unknown males, excluding the 252 genotyped individuals sampled within the studied plots. Based on the estimated pollen dispersal kernels and simulations, we inferred that the majority of background pollen likely originated from trees located within the forest complex and not surrounding forests. This implies that the genetic integrity of this population has the potential to be preserved. Therefore, actions promoting natural regeneration, or even the artificial planting of seedlings derived from seeds harvested in the core of the Polish larch population on Chełmowa Mountain, should be taken to increase the chance of sustainability of this valuable population.

Supplementary Materials: The following are available online at http://www.mdpi.com/1999-4907/10/12/1139/s1, Figure S1: Frequency distribution of actual local pollen dispersal distances within neighborhoods calculated based on inferred genealogies. Figure S2: Cumulative distribution of actual local pollen dispersal distances within neighborhoods calculated based on inferred genealogies. Figure S3: Frequency distribution of the number of offspring sired by individual males based on inferred genealogies. Figure S4: Frequency distribution of the number of offsprings per full-sib based on inferred genealogies. Figure S5: Variation of background pollination rates estimated for individual mother trees (red circles). The area of the red circle is proportional to the level of background pollination. Table S1: Study sites and characteristics of the adult populations of Polish larch in the two sample plots. Table S2: The estimates of genotyping error rates obtained based on the full mating model and power-exponential kernel, using the NM $\pi$ software. Table S3: Mating system characteristics of individual

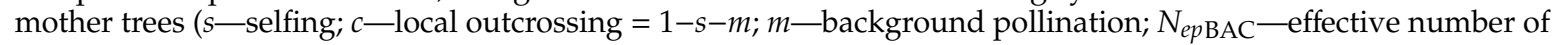




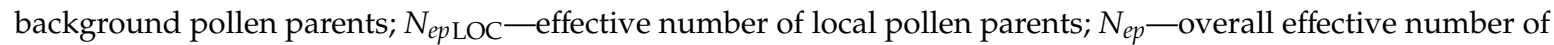
pollen parents).

Author Contributions: Conceptualization, J.B., E.S., and A.L.; methodology, J.B. and E.S.; data analysis, J.B. and E.S.; investigation, J.B., E.S., and A.L.; data curation, E.S.; writing-original draft preparation, J.B.; writing-review and editing, E.S. and A.L.; visualization, E.S.; project administration, J.B.; funding acquisition, J.B.

Funding: This study was supported by the Forest Fund of State Forests, Poland (grant number EZ.0290.1.30.2018), Świętokrzyski National Park, and the Polish Ministry of Science and Higher Education under the program "Regional Initiative of Excellence" in 2019-2022 (Grant No. 008/RID/2018/19).

Acknowledgments: The authors are thankful to Katarzyna Meyza and Ewa Sztupecka for laboratory assistance, and to Pawel Szczepaniak and Lech Buchholz from Świętokrzyski National Park for organizing sampling of material and providing data of the sample plots including tree measurements. The authors thank Igor Chybicki for his comments and discussion on the analyses of pollen dispersal patterns.

Conflicts of Interest: The authors declare no conflict of interest.

\section{References}

1. Rajora, O.P.; Mosseler, A. Challenges and opportunities for conservation of forest genetic resources. Euphytica 2001, 118, 197-212. [CrossRef]

2. Lefevre, F.; Koskela, J.; Hubert, J.; Kraigher, H.; Longauer, R.; Olrik, D.C.; Schuler, S.; Bozzano, M.; Alizoti, P.; Bakys, R.; et al. Dynamic conservation of forest genetic resources in 33 European countries. Conserv. Biol. J. Soc. Conserv. Biol. 2013, 27, 373-384. [CrossRef] [PubMed]

3. Koskela, J.; Lefèvre, F.; Schueler, S.; Kraigher, H.; Olrik, D.C.; Hubert, J.; Longauer, R.; Bozzano, M.; Yrjänä, L.; Alizoti, P.; et al. Translating conservation genetics into management: Pan-European minimum requirements for dynamic conservation units of forest tree genetic diversity. Biol. Conserv. 2013, 157, 39-49. [CrossRef]

4. Grumbine, R.E. What is ecosystem management? Conserv. Biol. 1994, 8, 27-38. [CrossRef]

5. Bengtsson, J.; Angelstam, P.; Elmqvist, T.; Emanuelsson, U.; Folke, C.; Ihse, M.; Moberg, F.; Nystrom, M. Reserves, resilience and dynamic landscapes. Ambio 2003, 32, 389-396. [CrossRef]

6. Ratnam, W.; Rajora, O.P.; Finkeldey, R.; Aravanopoulos, F.; Bouvet, J.-M.; Vaillancourt, R.E.; Kanashiro, M.; Fady, B.; Tomita, M.; Vinson, C. Genetic effects of forest management practices: Global synthesis and perspectives. For. Ecol. Manag. 2014, 333, 52-65. [CrossRef]

7. Aitken, S.N.; Yeaman, S.; Holliday, J.A.; Wang, T.; Curtis-McLane, S. Adaptation, migration or extirpation: Climate change outcomes for tree populations. Evol. Appl. 2008, 1, 95-111. [CrossRef]

8. Litkowiec, M.; Lewandowski, A.; Burczyk, J. Genetic status of Polish larch (Larix decidua subsp. polonica (Racib. Domin)) from Chełmowa Mountain: Implications for gene conservation. Dendrobiology 2018, 80, 101-111. [CrossRef]

9. Raciborski, M. Kilka słów o modrzewiu w Polsce. Kosmos 1890, 15, 488-497.

10. Boratyński, A. Systematyka i geograficzne rozmieszczenie. In Modrzewie (Larix Mill.), Nasze Drzezwa Leśne; t. 6; Białobok, S., Ed.; PWN: Poznań, Poland, 1986; pp. 61-107.

11. Wachter, H. Beobachtungen zum Verhalten einigen Lärchenprovenienzen gegenüber der Sommerdürre 1959. Silvae Genet. 1961, 10, 99-106.

12. Chylarecki, H. Modrzewie w Polsce-Dynamika Wzrostu, Rozwój i Ekologia Wybranych Gatunków i ras.; Bogucki Wydawnictwo Naukowe, S.C.: Poznań, Poland, 2000.

13. Pâques, L.E.; Sylvestre-Guinot, G.; Delatour, C. Variabilité clonale de la race polonica du mélèze d'Europe pour la résistance à Lachnellula willkommii. Ann. For. Sci. 1999, 56, 155-166. [CrossRef]

14. Jansen, S.; Geburek, T. Historic translocations of European larch (Larix decidua Mill.) genetic resources across Europe-A review from the 17th until the mid-20th century. For. Ecol. Manag. 2016, 379, 114-123. [CrossRef]

15. Bałut, S. Zmienność niektórych cech w populacjach modrzewia z Gór Świętokrzyskich, Beskidów i Sudetów jako podstawa wyróżniania gospodarczo cennych ekotypów. Acta Agraria et Silvestria seria Sylvestris II 1962, 3,43 .

16. Baranski, S. Wystepowanie i uprawy modrzewia rodzimego pochodzenia w Swietokrzyskich lasach rzadowych w pierwszej polowie XIX WIEKU. Acta Agr Silvestria Ser Lesna 1970, 10, 5-38.

17. Burczyk, J.; Difazio, S.P.; Adams, W.T. Gene flow in forest trees: How far do genes really trvel? For. Genet. 2004, 11, 179-192. 
18. Kremer, A.; Ronce, O.; Robledo-Arnuncio, J.J.; Guillaume, F.; Bohrer, G.; Nathan, R.; Bridle, J.R.; Gomulkiewicz, R.; Klein, E.K.; Ritland, K.; et al. Long-distance gene flow and adaptation of forest trees to rapid climate change. Ecol. Lett. 2012. [CrossRef]

19. Adams, W.T.; Burczyk, J. Magnitude and implications of gene flow in gene conservation reserves. In Forest Conservation Genetics: Principles and Practice; Young, A.G., Boshier, D., Boyle, T., Eds.; CSIRO Publishing: Collingwood, Australia, 2000; pp. 215-244.

20. Ellstrand, N.C. Gene Flow by Pollen-Implications for Plant Conservation Genetics. Oikos 1992, 63, 77-86. [CrossRef]

21. Trakhtenbrot, A.; Nathan, R.; Perry, G.; Richardson, D.M. The importance of long-distance dispersal in biodiversity conservation. Divers. Distrib. 2005, 11, 173-181. [CrossRef]

22. Smouse, P.E.; Sork, V.L. Measuring pollen flow in forest trees: An exposition of alternative approaches. For. Ecol. Manag. 2004, 197, 21-38. [CrossRef]

23. Nathan, R.; Klein, E.; Robledo-Arnuncio, J.J.; Revilla, E. Dispersal kernels. In Dispersal Ecology and Evolution; Oxford University Press Oxford: Oxford, UK, 2012; pp. 187-210.

24. Burczyk, J.; Adams, W.T.; Shimizu, J.Y. Mating patterns and pollen dispersal in a natural knobcone pine (Pinus attenuata Lemmon) stand. Heredity 1996, 77, 251-260. [CrossRef]

25. Torimaru, T.; Wennstrom, U.; Lindgren, D.; Wang, X.R. Effects of male fecundity, interindividual distance and anisotropic pollen dispersal on mating success in a Scots pine (Pinus sylvestris) seed orchard. Heredity 2012, 108, 312-321. [CrossRef] [PubMed]

26. Austerlitz, F.; Dick, C.W.; Dutech, C.; Klein, E.K.; Oddou-Muratorio, S.; Smouse, P.E.; Sork, V.L. Using genetic markers to estimate the pollen dispersal curve. Mol. Ecol. 2004, 13, 937-954. [CrossRef] [PubMed]

27. Ashley, M.V. Plant Parentage, Pollination, and Dispersal: How DNA Microsatellites Have Altered the Landscape. Crit. Rev. Plant Sci. 2010, 29, 148-161. [CrossRef]

28. Burczyk, J.; Lewandowski, A.; Chalupka, W. Local pollen dispersal and distant gene flow in Norway spruce (Picea abies [L.] Karst.). For. Ecol. Manag. 2004, 197, 39-48. [CrossRef]

29. Williams, C.G. How meso-scale pollen dispersal and its gene flow shape gene conservation decisions. New For. 2017, 48, 217-224. [CrossRef]

30. Di-Giovanni, F.; Kevan, P. Factors affecting pollen dynamics and its importance to pollen contamination: A review. Can. J. For. Res. 1991, 21, 1155-1170. [CrossRef]

31. Chybicki, I.J.; Oleksa, A. Seed and pollen gene dispersal in Taxus baccata, a dioecious conifer in the face of strong population fragmentation. Ann. Bot. 2018, 122, 409-421. [CrossRef]

32. Hardy, O.J.; Delaide, B.; Hainaut, H.; Gillet, J.F.; Gillet, P.; Kaymak, E.; Vankerckhove, N.; Duminil, J.; Doucet, J.L. Seed and pollen dispersal distances in two African legume timber trees and their reproductive potential under selective logging. Mol. Ecol. 2019. [CrossRef]

33. Chybicki, I.J.; Burczyk, J. Simultaneous estimation of null alleles and inbreeding coefficients. J. Hered. 2009, 100, 106-113. [CrossRef]

34. Do, C.; Waples, R.S.; Peel, D.; Macbeth, G.M.; Tillett, B.J.; Ovenden, J.R. NeEstimator v2: Re-implementation of software for the estimation of contemporary effective population size (Ne) from genetic data. Mol. Ecol. Resour. 2014, 14, 209-214. [CrossRef]

35. Adams, W.T.; Birkes, D.S. Estimating mating patterns in forest tree populations. In Biochemical Markers in the Population Genetics of Forest Trees; Fineschi, S., Malvolti, M.E., Cannata, F., Hattemer, H.H., Eds.; SPB Academic Publishing: Hague, the Netherlands, 1991; pp. 157-172.

36. Burczyk, J.; Adams, W.T.; Moran, G.F.; Griffin, A.R. Complex patterns of mating revealed in a Eucalyptus regnans seed orchard using allozyme markers and the neighbourhood model. Mol. Ecol. 2002, 11, 2379-2391. [CrossRef] [PubMed]

37. Chybicki, I.J. NMpi-improved re-implementation of $\mathrm{NM}+$, a software for estimating gene dispersal and mating patterns. Mol. Ecol. Resour. 2018, 18, 159-168. [CrossRef] [PubMed]

38. Chybicki, I.J.; Burczyk, J. Seeing the forest through the trees: Comprehensive inference on individual mating patterns in a mixed stand of Quercus robur and Q. petraea. Ann. Bot. 2013, 112, 561-574. [CrossRef] [PubMed]

39. Smouse, P.E.; Robledo-Arnuncio, J.J. Measuring the genetic structure of the pollen pool as the probability of paternal identity. Heredity 2005, 94, 640-649. [CrossRef] [PubMed]

40. Hartl, D.; Clark, A. Principles of population genetics. In Sunderland, Massachusetts, 4th ed.; Sinauer Associates: Sunderland, MA, USA, 2007. 
41. Ledig, F.T. The conservation of diversity in forest trees: Why and how should genes be conserved? Bioscience 1988, 38, 471-479. [CrossRef]

42. Paule, L.; Gömöry, D. Mating system in the seed orchards of European Larch (Larix decidua Mill.). In Population Genetics and Genetic Conservation of Forest Trees; SPB Academic Publishing: Amsterdam, the Netherlands, 1995; pp. 321-328.

43. Funda, T.; Chen, C.C.; Liewlaksaneeyanawin, C.; Kenawy, A.M.A.; El-Kassaby, Y.A. Pedigree and mating system analyses in a western larch (Larix occidentalis Nutt.) experimental population. Ann. For. Sci. 2008, 65, 705. [CrossRef]

44. Burczyk, J.; Kosiński, G.; Lewandowski, A. Mating pattern and empty seed formation in relation to crown level of Larix decidua (Mill.) clones. Silva Fenn. 1991, 25, 201-205. [CrossRef]

45. Lewandowski, A.; Burczyk, J.; Mejnartowicz, L. Genetic-Structure and the Mating System in an Old Stand of Polish Larch. Silvae Genet. 1991, 40, 75-79.

46. Hansen, O.K. Mating patterns, genetic composition and diversity levels in two seed orchards with few clones-Impact on planting crop. For. Ecol. Manag. 2008, 256, 1167-1177. [CrossRef]

47. Restoux, G.; Silva, D.E.; Sagnard, F.; Torre, F.; Klein, E.; Fady, B. Life at the margin: The mating system of Mediterranean conifers. Web Ecol. 2008, 8, 94-102. [CrossRef]

48. El-Kassaby, Y.; Jaquish, B. Population density and mating pattern in western larch. J. Hered. 1996, 87, 438-443. [CrossRef]

49. Lewandowski, A.; Burczyk, J. Mating system and genetic diversity in natural populations of European larch (Larix decidua) and stone pine (Pinus cembra) located at higher elevations. Silvae Genet. 2000, 49, 158-161.

50. Torimaru, T.; Wang, X.-R.; Fries, A.; Andersson, B.; Lindgren, D. Evaluation of Pollen Contamination in an Advanced Scots Pine Seed Orchard. Silvae Genet. 2009, 58, 262-269. [CrossRef]

51. Funda, T.; El-Kassaby, Y.A. Seed orchard genetics. Plant Sci. Rev. 2013, 2012, 21-43. [CrossRef]

52. Sjögren, P.; van der Knaap, W.O.; Huusko, A.; van Leeuwen, J.F. Pollen productivity, dispersal, and correction factors for major tree taxa in the Swiss Alps based on pollen-trap results. Rev. Palaeobot. Palynol. 2008, 152, 200-210. [CrossRef]

53. Levin, D.A.; Kerster, H.W. Gene flow in seed plants. In Evolutionary Biology; Springer: Berlin, Germany, 1974; pp. 139-220.

54. Wagner, S.; Liepelt, S.; Gerber, S.; Petit, R.J. Within-range translocations and their consequences in European larch. PLoS ONE 2015, 10, e0127516. [CrossRef]

55. Kruse, S.; Epp, L.S.; Wieczorek, M.; Pestryakova, L.A.; Stoof-Leichsenring, K.R.; Herzschuh, U. High gene flow and complex treeline dynamics of Larix Mill. stands on the Taymyr Peninsula (north-central Siberia) revealed by nuclear microsatellites. Tree Genet. Genomes 2018, 14, 19. [CrossRef]

56. Goto, S.; Shimatani, K.; Yoshimaru, H.; Takahashi, Y. Fat-tailed gene flow in the dioecious canopy tree species Fraxinus mandshurica var. japonica revealed by microsatellites. Mol. Ecol. 2006, 15, 2985-2996. [CrossRef]

57. De-Lucas, A.I.; Robledo-Arnuncio, J.J.; Hidalgo, E.; González-Martínez, S.C. Mating system and pollen gene flow in Mediterranean maritime pine. Heredity 2008, 100, 390-399. [CrossRef]

58. Sanchez-Robles, J.M.; Garcia-Castano, J.L.; Balao, F.; Terrab, A.; Navarro-Sampedro, L.; Tremetsberger, K.; Talavera, S. Effects of tree architecture on pollen dispersal and mating patterns in Abies Pinsapo Boiss. (Pinaceae). Mol. Ecol. 2014, 23, 6165-6178. [CrossRef]

59. Savolainen, O.; Pyhäjärvi, T.; Knürr, T. Gene Flow and Local Adaptation in Trees. Annu. Rev. Ecol. Evol. Syst. 2007, 38, 595-619. [CrossRef]

(C) 2019 by the authors. Licensee MDPI, Basel, Switzerland. This article is an open access article distributed under the terms and conditions of the Creative Commons Attribution (CC BY) license (http://creativecommons.org/licenses/by/4.0/). 